\title{
6. Stretching the sacred
}

\section{Elizabeth Burns Coleman and Kevin White}

The term sacred tends to be used interchangeably with a wide variety of terms: terms like mystical, religious, divine, magical, and, most commonly, spiritual and religious. In 2002, the Humanities Research Centre at The Australian National University ran a conference entitled 'Locations of Spirituality: "Experiences" and "Writings" of the "Sacred"'. All of these topics were addressed in the papers presented at the conference. On one level this suggests that the term 'sacred' is inherently vague.

Yet there are some features the uses seem to have in common. A writer for the Encyclopedia of Religion and Society, Edward Bailey, has suggested that the realm of those things we might call sacred is generally recognised as possessing four characteristics:

in experience, it is special, and even unique; in value, it is important, even all demanding; in consciousness, it is fundamental, even primordial; in communication, it is dynamic, yet ineffable... All these characteristics issue a single consequence that is easily described but is less a separate quality than an aspect or by product of all of them: It imposes "taboos", restrictions. ${ }^{l}$

The term 'sacred' tends to be used synonymously with 'religious', and it is not uncommon to see people using the terms interchangeably. Yet, when someone says 'this is sacred land', they may or may not be introducing a particular religious framework into a discussion. But they are implying that something normative follows from their statement. The issue that we wish to explore in this paper is the normative force of the attribution of sacred as a quality. What does it mean to say that something is sacred, and does it always have the same normative force across different usages?

The term sacred is stretched beyond 'religion', leaving traditional truths and virtues behind it, and used interchangeably with terms like 'spiritual'. A person need not recognise the authority of any religion, and may insist upon a highly individualistic claim to the truth or validity of their experience. Certain kinds of experience might be considered an experience of the 'sacred'. We might include amongst these altered states of consciousness such as ecstasy, a special way of knowing or hyper-consciousness, visions and auditions, the experience of paranormal or occult phenomena, or the experience of a connection with the earth, for example, as in 'nature mysticism'. 
The term sacred is also applied secularly, in relation to such things as the State, memorials and ANZAC Day, and even property. The stretching of 'the sacred' to this application of the term sacred was made possible through the analysis of the concept within the social sciences, in particular, by Emile Durkheim. At the same time, Durkheim's analysis 'closes down' other applications of the term, such as the use of the term sacred to personal feelings and spiritual sentiments. Durkheim's concept of the sacred suggests that the use of the term has normative force only in connection with authority, and that therefore the personal use has none.

In the first part of the paper, we will consider Durkehim's analysis of the sacred, and the way this has been applied within the social sciences, and extended to secular society. The second part addresses Durkheim's idea that the sacred and profane are necessary, and opposite, categories and the normative content of the concept. Anthropologists have criticised Durkheim's analysis on the basis that the binary does not seem to operate in every society. Different metaphysical conceptions, as well as different understandings of the relationship between religion, spirituality and secular institutions and 'the sacred' have different implications for what might be considered taboo. Moreover, the duality sacred/profane does not seem to fully explain the normative content of the relationship in its common usages. In the third part, we will suggest a third way of understanding the normative content of the claim that something is sacred - and argue that the mobilization of the term sacred may involve different, and heterogeneous norms.

\section{Durkheim and 'the sacred' in the social sciences}

Before Durkheim, in the works of Tylor, ${ }^{2}$ Mueller $^{3}$ and Fraser, ${ }^{4}$ religion was considered as a property of the individual, as the individual's reaction to nature, or a series of delusions. Even William James did not break with this tradition. For William James the sacred and its experience is variable, dependent on the individual, and has its authority from the psychological experience of the individual. His focus is on religious feelings and impulses as related by individuals. He ignores the 'institutional branch of religion' completely focusing on 'that which lives itself out within the private breast'. ${ }^{5}$ Alternatively, for Durkheim the sacred is specific and independent of the individual, based in communal action and ritual, evoking emotional responses of belonging and awe in the believer. He specifically criticises James for neglecting institutions and churches. The sacred is neither about feelings of brotherhood or a matter of voluntary association. It is a social imperative that affirms society and binds the individual to it. Against James, Durkheim argues that religion is not about belief in $\operatorname{god}(\mathrm{s})$ but in the distinction between the sacred and the profane. This was a very powerful analytic move on Durkheim's part and substantially shaped the sociology of religion. 
Durkheim's approach was itself shaped by William Robertson Smith's Lectures on the Religion of the Semites ${ }^{6}$ (1889) which argues that the sacrificial meal between god and men produces a sacral community and which Durkheim read in 1912, and Fustel Coulanges', The Ancient City ${ }^{7}$ (1901) in which Coulanges argued that the religion of Ancient Rome reflects the social structure of Roman society. ${ }^{8}$

As always Durkheim is arguing against liberalism and pragmatism. No account of social life can be based on contractual theories, nor is a religion a set of 'truths' which hold good because they work for the individual (James' position). Rather religious beliefs provide the basis for social action and are based on the truth of society. What does religion function to do? It creates a social bond; it remakes social commitments through the 'effervescence'; it produces individuals who are versed in sacrifice and asceticism, which result in altruism and social service; and in bringing the group together around collective ritual it maintains the collective memory of the group, thereby producing continuity over generations. ${ }^{9}$ As Durkheim puts it in The Elementary Forms of the Religious Life, religion is,

the way societies become conscious of themselves and their history...The gods are no other than collective forces personified and hypostasised in material form. Ultimately, it is the society that is worshipped by the believers; the superiority of the gods over men is that of the group over its members. The early gods were the substantive objects which served as symbols to the collectivity and for this reason became representations of it. ${ }^{10}$

Durkheim attacks, then, individualist accounts of religious experience and provides his famous definition of religion as that 'unified system of beliefs and practices relative to sacred things, that is to say, things set apart and forbidden - beliefs and practices which unite into one single moral community called a Church all those who adhere to them'. ${ }^{11}$ The importance of this definition is that religion is defined in terms of the sacred, not the sacred in terms of religion. This allows Durkheim to subsequently explore the non-religious aspects of the sacred in his exploration of what is going to hold a society with a weak conscience collective together.

Durkheim develops his argument on two fronts. On the one hand he argues that religion is a manifestation of the collective values of society. On the other, society is held together by religious beliefs. Religion is thus central to social solidarity and represents social solidarity. Durkheim's two arguments can be labelled as a 'religion to society' analysis, and as a 'society to religion' analysis. 


\section{Religion to society}

Durkheim sees religion as the deep grammar of society because religion is the source of social norms; and social norms have the quality of religious obligation. Religion is the pre-contractual foundation of social solidarity. It is custom, ritual and morality that make contracts binding. As is well known, Durkheim also locates the categories of thought in religion.

\section{Society to religion}

Religion is a social fact. All societies are based on collective representations. But the religion is not just a collective representation. It is the symbol of the collective identity. It stands above any given collective representation, integrating all of them. As Pickering ${ }^{12}$ puts Durkheim's position, the society-religion and the religion-society circuit is that the sacred is 'a fundamental element in the ordering of society' and the representation of collective ideals and beliefs.

It is important to note that Durkheim is defining religion in terms of the sacred, not the sacred in terms of religion. This moves him away from his institutional definition of religion as a church and generalises the concept of the sacred beyond religion. 'The sacred is the concept associated with the collective ideas represented through religious symbols and metaphors'. There can be no society without the sacred, since the sacred is society's idealised vision of itself. As Durkheim puts it:

There can be no society which does not feel the need of upholding and reaffirming at regular intervals the collective sentiments and collective ideas which make its unity and its personality. Now this moral remaking cannot be achieved except by means of reunions, assemblies and meetings where individuals, being closely united to one another, reaffirm in common their common sentiments, hence come ceremonies which do not differ from regular religious ceremonies, either in their object, the results they produce or the processes employed to obtain the result. ${ }^{13}$

With the decline of religion, Durkheim suggests that nationalist sentiment and national ceremonies provide social cohesion. In Professional Ethics and Civic Morals 14 Durkheim points to 'a cult of the state' worshipped by citizens in which patriotism, 'the ideas and feelings as a whole which bind the individual to a certain state', performs the function of the sacred.

Another location of sacred, Durkheim suggests, is the 'cult of the individual'. As the division of labour becomes more complex, society invests more in each individual, resulting in the individual becoming sacred. 'Morality would no longer be morality if it had no element of religion... The respect which we have for the human being is distinguishable only very slightly from that which the

faithful of all religions have for the objects they deem sacred'. ${ }^{15}$ 'Society has 
consecrated the individual and made him pre-eminently worthy of respect ${ }^{\prime}{ }^{16}$ While Durkheim had developed this theme in Suicide and in The Division of Labor in Society, its strongest statement is to be found in his essay 'Individualism and the Intellectuals' in which he states that the:

human person (personne humaine), the definition of which is like the touchstone which distinguishes good from evil, is considered sacred in the ritual sense of the word. It partakes of the transcendent majesty that churches of all time lend to their gods; it is conceived of as being invested with that mysterious property which creates a void about sacred things, which removes them from vulgar contacts and withdraws them from common circulation. And the respect which is given comes precisely from this source. Whoever makes an attempt on a man's life, on a man's liberty, on a man's honor, inspires in us a feeling of horror analogous in every way to that which the believer experiences when he sees his idol profaned. Such an ethic is therefore not simply a hygienic discipline or a prudent economy of existence; it is a religion in which man is at once the worshipper and the god. ${ }^{17}$

He also says the same thing about property: Property is property only if it is respected, that is to say, held sacred. ${ }^{18}$ This is explained by his insistence that the right of property consists in essence as 'the right to withdraw a thing from common usage', and that this feature of property is shared by 'all religious and sacred things' 19

What all these things that might be considered sacred have in common is that they are exclusionary. Durkheim says,

The feature that distinguishes the sacred entities is that they are withdrawn from general circulation; they are separate and set apart. The common people cannot enjoy them. They cannot even touch them. Those who would have a kinship, as it were, with sacred things of this kind, can alone have access to them - that is, those who are sacred as they are: the priests, the great, the magistrates, especially where the latter have a sacred character'.20

This extension of the sacred away from institutional churches has been influential in twentieth century social theory. For Berger, following Durkheim, cognitively, the sacred orders chaos and a 'rumour of angels' ${ }^{21}$ is present even in modern society. Callois, ${ }^{22}$ like Durkheim, analysed religion as the deep grammar of society, even in modern societies, arguing that public space is divided into the sacred and profane. In Canberra, for example, we have Parliament, and the War Memorial, laid out as the axis of the city, with Anzac Parade linking them. Industrial suburbs, which include the brothels, are located on the outskirts of the city, as are the tips. The sacred is thus an organising factor in the way we 
lay out our cities. In this analysis, at the centre of modern societies is the sacred. A similar argument had been advanced by de Tocqueville in 1832, and then most influentially in the twentieth century by Bellah ${ }^{23}$ with his concept of civil religions. Thus it is argued that modern societies are deeply religious, if secularised, and they have to recognise the power of the sacred in their own societies. Parsons has suggested, and subsequently Habermas, that the normative content of modernity is produced by 'the Hebrew morality of justice in the Old Testament and the Christian ethics of love in the New Testament' ${ }^{24}$ Modernity is still sacred, if not religious.

The moral force of the sacred-profane distinction Durkheim tends to equivocate between religion and sacred in his texts. The religious is defined in terms of the sacred, but he will often refer to the religious, rather than the sacred, as the source of moral rules.

The sacred may be defined as those things set apart, and identified by taboos, which set it apart from the profane. The profane, the opposite of the sacred, is not a clear concept. Durkheim never defines it although commentators have listed its characteristics as 'ordinariness', 'work', 'individual', or the 'body'.

According to Durkheim, in both modern and pre-modern life, morality can be defined by the interdictions of taboos around the sacred. 'It is impossible to imagine on the evidence,' Durkheim states, 'that morality should entirely sever its unbroken historic association with religion without ceasing to be itself' ${ }^{25}$ In Professional Ethics and Civic Morals he argues, 'Man is a moral being only because he lives within established societies. There are no morals without discipline and authority... Morals do not seem like obligations to us, that is, they do not seem like morals to us - and therefore we can have no sense of duty - unless there exists about us and above us a power which gives them sanction' ${ }^{26}$ What is clear in this comment is that the moral injunctions are those that preserve the sacred - and are based on a rules/duty model of morality. These rules are the sanctions or taboos around the sacred. In a sense, the taboos maintain and preserve the sacred. Durkheim goes on to acknowledge that individuals develop their own image of God and spirituality, but this cannot be a source of ethics for Durkheim. He argues that it is the authoritarian, and not the individual, conception of the sacred that is the source of ethics on the grounds that if the authority of the state is weakened, the sense of duty and therefore of ethics is also weakened, and this leads to a general anarchy and immorality.

Importantly here, individual experience or sentiment could not be considered 'sacred' on Durkheim's account, and cannot generate any moral force. As pointed out in the introduction, this is one of the most common features of the contemporary usage of the term. This is not necessarily a significant point against Durkheim's analysis, as it could be that the usage is a form of rhetoric that borrows its force from the Durkheimian juridical sense. Furthermore, to the 
extent that Durkheim's definition is stipulative, a way of using terms to identify and discuss a specific phenomenon, there is no reason not to exclude some uses. More pertinent objections are that the distinction does not seem to account for the morality and behaviour that Durkheim suggests it does, and that even where the distinction is found in other cultures, it does not necessarily have the features Durkheim suggests it does. This evidence points to Durkheim failing to give a definition that will achieve what he sets out to explain cross-culturally- the relationship between social structure and religion.

\section{The sacred-profane distinction and the effects of 'effervescence'}

The first objection is that it is not clear that the taboos that maintain and preserve the sacred can also generate and explain altruism and social service through 'effervescence'. Durkheim appears to be using one ethical code or structure, that is a rules/duty framework to explain the existence of virtue ethics.

On one level, Durkheim's definition of the sacred is not unlike that of the Catholic Church. What both rule out is the idea that 'sacrilege' could ever involve something other than a rule by an authority. For instance, the New Advent Catholic Encyclopaedia defines the sacred as a juridical category-only those things that the Church has decided are sacred are sacred, the sacred in this sense is something that has been consecrated, it is a special status. Joseph Delany writes,

Theologians are substantially agreed in regarding as sacred that and that only which by a public rite and by Divine of ecclesiastical institution has been dedicated to the worship of God. The point is that the public authority must intervene; private initiative, no matter how ardent in devotion or praiseworthy in motive, does not suffice. Attributing a sacred character to a thing is a juridical act, and as such is a function of the governing power of the Church. ${ }^{27}$

This means that, according to the writers of the New Advent, there are a great many religious things that are not sacred. Hence they make a distinction between crimes of sacrilege, properly so called, which is the violation or injurious treatment of a sacred object, and transgressions against the virtue of religion, such as superstition, blasphemy and perjury, simony, idolatry and superstition, that might be commonly, and improperly, referred to as sacred.

While there is some similarity between Durkheim and the Catholic definition of the sacred, there are also significant differences. For one thing, Durkheim reduces all morality to a juridical morality, whereas the Catholic definition does not.

Durkheim appears straightforwardly wrong on this point, and there appear to be many moral codes that are not based in the sacred as he describes it - for 
example, the ethics of care, or loyalty to friends, and civic and religious virtues - that cannot be explained by reference to an authoritative source. Secondly, the New Advent recognises that although not crimes against the sacred, there are other moral values associated with religion, including a number of virtues.

Rules spell out a minimal action-they do not reflect aspirations. No-one is obliged to become a saint, or to live a life of devotion, even if they are expected to observe the rules of a religion, and practise, to the extent that they are able, the virtues. However, they are excused for failing to achieve virtues in a way that they are not excused for failing to observe rules. Durkheim might still argue that the virtues, such as good citizenship or devotion, are based on collective representations of the good, but he cannot argue that the ethics involved in these collective representations all depend on a rule-bound moral code.

\section{The sacred-profane distinction is not universal}

As W. S. F. Pickering ${ }^{28}$ points out, from its earliest reception the duality of the sacred and profane in Elementary Forms has been seriously questioned. Even pupils loyal to Durkheim such as Marcel Granet ${ }^{29}$ found in his empirical work on religion in China that the dualism was not marked. Evans-Pritchard, ${ }^{30}$ in his studies of the Azande rejected it flatly, arguing that the two categories intermingled and were inseparable and did not negate each other. Most damaging though has been the work of Stanner, ${ }^{31}$ based as it is on fieldwork with Australian Aboriginals. Remember that the basis of Durkheim's distinction between the sacred and profane is that religious thought reflects social organisation. Durkheim asserts that since no individual can be a member of two moieties that it is this radical separation that is reflected in the religious thought and the basis of the distinction between the sacred and the profane. Stanner's fieldwork shows that in fact members of different moieties do intermingle and that the moieties are not radically distinct. Groups can and do intermix while still preserving their identities and hence neither their social organisation, nor their conceptual thinking, reflects the dualism that Durkheim ascribes to them. What these objections show is that the distinction between sacred and profane that Durkheim develops does not explain all the features of societies that recognise something like a realm of the sacred, and that the concept of the sacred does not necessarily have the features that Durkheim suggests.

Part of this divergence between theory and reality can be explained by the fact that there is an equivocation in Durkheim's concept of the binary, as there is in the word 'profane' itself. The profane may simply mean 'not sacred', but it also has a meaning of being irreligious, and a misuse or abuse of the sacred, which might be termed the 'anti-sacred'. That these are different binaries can be shown logically. If, like Durkheim, you define the sacred as that which is set apart, 
then the profane defined as non-sacred, that is, as the every-day or ordinary, is a necessary condition for the concept. It is impossible to imagine a world in which some things are set apart, but nothing is ordinary. However, the profane as 'anti-sacred', that is, as acts against the sacred, is not a necessary condition for the concept of the sacred. While the sacred as 'set apart and preserved by taboos' requires rules to establish the sacred as a social fact, it does not require anyone to break those rules. It is possible to imagine a world in which there are things that are sacred, but that no-one ever breaks the rules. However, it is not necessary that we do define 'the sacred' as that which is set apart.

In his fieldwork, Jack Goody found that the Lo Dagaa of northern Ghana make no recognisable distinction between the natural and the supernatural. He wrote: 'But neither do the Lo Dagaa appear to have any concepts at all equivalent to the vaguer and not unrelated dichotomy between the sacred and the profane'. ${ }^{32}$ The fact that the sacred is not universal should not surprise us, as different cultures also understand the world in different ways. The ways in which the different groups and people explain the world, and the relationship between the spiritual and natural world, will affect the usefulness of the term. If you think that God, or the spirit of the world, is immanent, you will have a world in which the entire world is endowed with spiritual importance. If you describe this idea of 'spiritual importance' as the sacred, everything will be sacred, however, the conception of the sacred you will be using will be nothing like that which Durkheim uses, because there is nothing that distinguishes it from the ordinary. However, as we will argue in the next section of this paper, this does not mean that your usage cannot have normative force, merely that the normative force of the claim will be nothing like Durkheim's sacred-profane distinction. In the next section of the paper we intend to analyse some of the common uses of the term, and the norms associated with their use.

\section{The uses of the term 'sacred' and their normative content}

So what does it mean when some-one says 'this land is sacred'? Following Wittgenstein's dictum that meaning is use, some theologians are now exploring the concept of the sacred in terms of its usage, giving up on the attempt at a definition. As we will show, adopting this approach this does not necessarily mean giving up Durkheim's analysis, but it does recognise the heterogeneity of moral sentiments, and give a fuller account of the ethical force of the use of the term.

For instance, Frederick Ferre and James Ross suggest that religious language serves a number of related functions:

- The expressive - that is, language to express and evoke certain feelings;

- The pragmatic - that is, language to modulate and facilitate behaviour; 
- The performative - language that actually accomplishes certain kinds of behaviours, such as confirmation, baptism and marriage; and

- The cognitive - language that involves a commitment to certain facts about the world, as well as to a vision of life based on those facts. ${ }^{33}$

However, if, as has been assumed, the invocation of the term sacred always includes a normative force or taboo, then it always contains some kind of pragmatic force about the modulation of behaviour. Moreover, analysing the invocation of the term sacred is more specific than analysing 'religious language' in general. Hence, for this to address our question, what is the normative force of the use of the term 'sacred', we will need to adapt the analysis. We intend to categorise the use of the term sacred into three uses, giving up pragmatic as a separate category: these uses are expressive, aspirational, and juridical.

The expressive use of the term sacred involves people's feelings and intuitions. This might include what has been called by Antoine Vergote ${ }^{34}$ the pre-religious experience; for example, experiences that focus our existence in the world and its meaning. This would include 'nature mysticism', the world and its existence (as in some physicists' response to the universe), the love we have for another, or the ethical quest. Vergote argues that these experiences all have in common the sense that they are 'supported and penetrated by a transcendent' but are not 'religious experiences', which he defines as the immediate presence or given-ness of the divine. We will also include in this category experiences of altered states that might be termed 'spiritual' or altered states of consciousness in general, such as out of body experiences, or a general sense of a divine presence. The expressive, for example, excludes us from commentary. It is protected from criticism by being too personal, a disclosure that does not allow a point of criticism or jest without offence. The taboo is a taboo based on the respect for persons and their feelings. Consider, for example, roadside memorials to the dead, the symbol and expression of love and remembrance. For Durkheim, such memorials could not be considered sacred - they are individual, sentimental, and do not involve a collective representation. Yet at the same time, they are left untouched by vandals. The taboos surrounding the desecration of memorials need not be, as Durkheim suggests, merely due to the representations as representations of the state or civic duties.

Aspirational uses include, on this account, in addition to a sense of presence of the divine, or a transcendent good, a commitment to a way of life. This might be akin to mystical experiences, and conversion. We are borrowing here not only from the idea of what Ferres calls a cognitive use of religious language, but from William James, who discusses conversion in terms of how a person is changed through experience: he argues that in addition to an experience of some kind, a person who undergoes spiritual conversion attains a new set of values, a way of life in the world. Similarly, the mystical experience is associated with 
a direct experience of the divine, and a commitment to a way of life. The important point here is not that it is an intuition of the immediacy of the divine, but that it translates itself into a way of acting in the world, hence the choice of the term aspirational - by which we mean acting on the basis of a 'truth'. The mystical appears to involve a virtue ethics, an attempt to lead a way of life, and a driven-ness to achieve it.

The third category, the juridical, includes the Durkheimian concept of the sacred as set apart, and involves the recognition of rule-based sanctions, as well as the recognition of what we have been discussing as the anti-sacred. The juridical concept is deontological, and based on a respect for authority and tradition.

In her abstract for the Locations of Spirituality conference, Diana James wrote:

One early morning I was driving west along a familiar dirt road through sand dune and desert oak country. The sky ahead changed gradually from dark blue to pale as light seeped in. When the first spears of the sun shot the spinifex with gold, I stopped and jumped out of the car. My face turned to greet the sun, the eternal fire burning on the rim of the world between earth and sky. Then I knew the sun was the Son, the light of the world. Born of the union of mother earth and father sky. The young desert oaks stood still in reverence as new initiates, while their elders intoned a hymn played by the wind of dawn... The realm of the sacred must be entered and understood in it's own [sic] terms. The tools of rationality are clumsy and inappropriate in this non-material dimension of reality. Sacred space is alive with paradoxes, mystery and magic. Whether it be a cathedral well or a rockhole in the desert, it contains the water of life. ${ }^{35}$

James's comments are not deontological, and do not recognise the distinction between a cathedral as a sacred space, consecrated through the church, and a rock hole. She draws on religion, but recognises none. Nor is her experience related to some kind of virtue ethic about the relationship between land and humans and the land. Rejecting rationality, and not invoking a virtue ethics that might imply 'failure' of some kind, it also rejects criticism.

Contrast this with Michael Williams's abstract, for his paper at the same conference, 'Journeying with Respect':

This presentation will be a ranging commentary on my life's journey - reflecting on how I came to this point. It will be my attempt to make sense of things as I see them and how they have come to be in my life. It will draw on my families [sic] stories and the way that the several generations of my family have been touched by an insistence on/of the efficacy of our old ways, our law and how respect for all these things have influenced my own life and the affairs of other things - how 
things, people, places and broader have been affected by a 'taking of care' approach to responsibilities. $^{36}$

Williams, an Aboriginal man from South East Queensland, makes reference to a juridical concept of the sacred; what is sacred is sacred by law, the law gives obligations and duties. What he says can be entered into, debated and discussed as an interpretation of law.

These people are saying different things, and the word sacred should not be interpreted as meaning the same things in these cases. It is based on a different conceptual understanding of the world, or metaphysics, and has different implications for action. One question it does raise is the issue of intolerance. Where spiritualism sees itself as being free from the constraints and dogmatism of organised religion, one claim (that based on religious law) is debatable, while the other (based on personal sensibility) is not. In conclusion, we do need to extend the term sacred to the personal, but at the same time, we need to recognise that different metaphysical conceptions of the world, and different experiences, will produce different normative implications. To understand the sacred, we need to pay closer attention to these metaphysical frameworks, and to allow a broader understanding of its normative force.

\section{ENDNOTES}

1 Swatos, W. H. Jr. (ed.) 1998, Encyclopaedia of Religion and Society, Hartford Institute for Religion Research, Hartford Seminary, Walnut Creek, Altamira Press, <http://hirr.hartsem.edu/ency/Sacred.htm>

2 Tylor, E. B. 1891, Primitive Culture: Researches into the Development of Mythology, Philosophy, Religion, Language Art and Custom, London, J. Murray.

3 Muller, F. M. 1893 Introduction to the Science of Religion, London, Longman Green.

4 Fraser, J. G. 1923-27, The Golden Bough: A Study in Magic and Religion, London, Mamillan.

5 James, W. 1985 [1902], The Varieties of Religious Experience, London, Penguin.

6 Smith. W. R. 1907, Lectures on the Religion of the Semites, London, A. and C. Black.

7 De Coulanges, F. 1900, The Ancient City, Boston.

8 Pickering, W. 1984, Durkheim's Sociology of Religion, London, Routledge and Kegan Paul, p. 47.

9 Wach, J. 1949, Sociology of Religion, Chicago, University of Chicago Press.

10 Durkheim, E. 1965 [1915], The Elementary Forms of the Religious Life, trans. J. W. Swain, New York, Free Press.

11 Durkheim, 1965, p. 62.

12 Pickering, 1984, p. 187.

13 Durkheim, 1965, pp. 474-5.

14 Durkheim, E. 1953, Professional Ethics and Civic Morals, Westport, Greenwood Press, p. 73.

15 Durkheim, E. 1974, Sociology and Philosophy, New York, Free Press, p. 68.

16 Durkheim, 1974, p. 72.

17 Durkheim, E. 1973, 'Individualism and the Intellectuals', in R. Bellah, (ed.) Emile Durkheim on Morality and Society, Chicago, University of Chicago Press, p. 46.

18 Durkheim, 1953, p. 159.

19 Durkheim, 1953, pp. 142-3.

20 Durkheim, 1953, p. 143.

21 Berger, P. 1969, A Rumour of Angels: Modern Society and the Rediscovery of the Supernatural, New York, Doubleday. 
22 Callois, R. 1939, L'Homme et la Sacre, Paris, Gallimard.

23 Bellah, R. 1967, 'Civil Religion in America', Daedulus, no. 96, pp. 1-21.

24 Habermas, J. 1999, 'A Conversation About God and the World' in J. Habermas and E. Mendieta (eds) Reason and Religion, Cambridge, Polity, p. 427. Parsons, T. 1999, 'Christianity and Modern Industrial Society', in B. S. Turner (ed.) The Talcott Parsons Reader, Oxford, Blackwell.

25 Durkheim, 1974, p. 69.

26 Durkheim, 1953, p. 73.

27 Delany, Joseph F. 2003, 'Sacrilege', New Advent Catholic Encyclopaedia, <http://www.newadvent.org/cathen/1332la.htm>, viewed 16 January 2006.

28 Pickering, 1984, pp. 143-9.

29 Granet, M. 1975 [1922], The Religion of the Chinese People, trans. M. Freedman, Oxford, Basil Blackwell.

30 Evans-Pritchard, E. 1937, Witchcraft, Oracles and Magic Among the Azande, Oxford, Clarendon Press.

31 Stanner, W. 1967, 'Reflections on Durkheim and Aboriginal Religion', in M. Freedman (ed.), Social Organization: Essays Presented to Raymond Firth, London, Frank Cass.

32 Goody, J. 1961, 'Religion and Ritual: The Definitional Problem', British Journal of Sociology, no. 12, pp. 142-64, quotation at p. 151.

33 See <http://members.optusnet.com.au/ gjmoses/relexpl.htm>

34 Vergote, Antoine 1995, 'Debate Concerning the Psychology of Religion', International Journal for the Psychology of Religion, vol. 5, pp. 119-24.

35 James, Diana 2002, 'How can we sing our own songs in a strange land?', Locations of Spirituality: 'Experiences' and 'Writings' of the Sacred, Humanities Research Centre, Old Canberra House, Australian National University, 26-27 October 2002, <http://www.anu.edu.au/hrc/conferences/conference_archive/2002/LocationsofSpirituality_abstracts.php>, viewed 16 January 2006.

36 Williams, Michael 2002, 'Journeying with Respect', Locations of Spirituality: 'Experiences' and 'Writings' of the Sacred, Humanities Research Centre, Old Canberra House, The Australian National University, 26-27 October 2002, <http://www.anu.edu.au/hrc/conferences/conference_archive/2002/LocationsofSpirituality_abstracts.php >, viewed 16 January 2006. 